\title{
Governance, Risk Management Index, and Performance: A Comparative Study of Indonesian Islamic Compliant and Non-Compliant Firms
}

\author{
Husaini $^{1}$ and Saiful ${ }^{2}$ \\ \{husain34@yahoo.com¹, saifulak@yahoo.com² \\ ${ }^{1,2}$ Accounting Department, Bengkulu University, Indonesia
}

\begin{abstract}
The aim of this study is to test whether the performance of Islamic compliant companies is better than noncompliant companies. This research also examines whether Board Size, Board independence and Enterprise Risk Management (ERM) influence the Performance of those companies. The sample in this study is non-financial companies listed on the Indonesia Stock Exchange period 2011-2015, with a total of 95 Islamic compliant and 858 non-Islamic compliant companies. This study found that Islamic compliant performance is higher than non-Islamic compliant companies. Further, the findings of this study show that board size has no relation to the performance of those companies. While board independence has a negative relation to the performance of the companies. This study also found ERM positively affects the performance of both Islamic compliant and non-Islamic compliant companies.
\end{abstract} $\begin{aligned} & \text { Keywords: } \\ & \text { compliant }\end{aligned} \quad$ Board size, Board independence, ERM, performance and Islamic

\section{Introduction}

The development of sharia business is increasing along with the awareness of Muslims to run business based on the Islam guide. This development also includes their participation in the halal investment in the capital market. This phenomenon can be seen from the existence of spikes of religious aware investors among Muslims. These investors trend to embed only in companies that run businesses in the manner permitted by Islamic rules (Sanusi et al., 2006). In Indonesia, since 2000 the Indonesia Stock Exchange created Jakarta Islamic Index (JII) covering 30 stocks whose business activities comply to Islamic principles that based on the National Sharia Council (DSN) fatwa. The launching of JII makes investors have an alternative in investing, especially halal investment because investors who have awareness of religion tend to invest in companies in accordance with sharia (Omran, 2009).

JII gives Muslim investors a guidance in selecting the stocks which provide high return and low risk among 30 stocks that listed in the index. The purpose of Islamic business not only for profit (Arham, 2010) but also for the healthy business climate, sustainable and good governance (Beekun, 1997). However, in order to give confidential for Muslim investors, the companies that listing in JII (shariah-compliant companies) should provide preferable performance than different companies (non-shariah compliant companies). Some previous studies concluded that firm performance in modern business perspective is influenced by board size, Board independence, and enterprise risk management (ERM). Meanwhile, resource dependence theory that the larger board size will be followed by better firm performance (Anum Mohd Ghazali, 2010), Moreover, some studies found that the large board size will increase the effectiveness of corporate oversight, which will have an impact on improving firm performance (Pearce and Zahra, 1992; Kumar Adhikary, Huynh Gia Hoang Bishnu Kumar Adhikary and Huynh Gia Hoang, 2014; Haider, Khan and Iqbal, 2015). In contrast, (Hermalin and Weisbach, 2001)conclude that small board size tends to improve firm performance (JENSEN, 1993; Yermack, 1996; Nisha and Ghosh, 2018).

Furthermore, according to stakeholder theory that the proportion of highly board independence will improve firm performance ((Dahya, Dimitrov and McConnell, 2008; Juras and Hinson, 2008; Black and Kim, 2012; Bukair and Abdul Rahman, 2015; Fuzi, Halim and Julizaerma, 2016). The implementation of ERM as part of corporate governance also has an influence on improving company performance and can lower agency costs (Schroeck, 2002). Furthermore, ERM uses risk appetite, to determine which risks should be received, and the risks to be mitigated or avoided by the company (Pagach and Warr, 2010).

The objective of this study is to examine whether there is a distinction in company market performance, governance, and risk management implementation in Islamic compliant and nonIslamic compliant companies. This study also tests the relation between governance structure and risk management implementation on the market performance of both Islamic and non-Islamic compliant companies. 


\section{Literature Review}

\subsection{Performance of Islamic Compliant and Non-Islamic Compliant Companies}

Reference (Farooq and Alahkam, 2016) state that sharia firms have low leverage and accounts receivable are associated with lower bankruptcy risk and lower non-payment risks. It indicates the Islamic economic principle can make the financial system more stable and resistant to shocks. The implementation of risk management is also very important especially if the company is included in Islamic compliant because risk or uncertainty can be considered as 'gharar' and hence, should be avoided in investment. Therefore a Shariah-compliant company must minimize its risk or uncertainty (Sanusi et al., 2006)

\subsection{Boar of Director, Board Independence and Firm Performance}

Corporate governance in Islamic finance becomes a necessity especially when the level of awareness of Muslims in choosing an investment based on sharia is increasing. High public perceptions of sharia firms and expect companies to set best practices in accordance with corporate governance rules and sharia requirements (Safieddine, 2009). Reference (Hermalin and Weisbach, 2001) declare the establishment of a Board of Directors in an important company as an internal control mechanism to oversee manager behavior, and in Islamic financial institutions, the main roles of the board of directors are to regulate and approve policies and strategies as a whole, to monitor the achievement of company goals, ensure management accountability and to protect shareholders (Chapra and Ahmed, 2009).

Reference (Anum Mohd Ghazali, 2010) explains, however, that resource dependence theory suggests that larger board sizes will result in better corporate performance because different skills, knowledge, and skills are elaborated in discussions in the boardroom. In contrast, Reference (JENSEN, 1993) argues that the small board tends to improve the company's performance. Likewise, Reference (Hermalin and Weisbach, 2001)suggest that larger board are less effective, because when the board is too large often act only as a symbol. In line with that view, empirical studies have shown inconsistent results between the relationship between board size and company performance. For example, References (Chin, Vos and Casey, 2004; Anum Mohd Ghazali, 2010) do not show the influence between board size and performance. References (Yermack, 1996) and (Ghosh, 2014) found a negative influence between board size and company performance. While (Pearce and Zahra, 1992; Kumar Adhikary, Huynh Gia Hoang Bishnu Kumar Adhikary and Huynh Gia Hoang, 2014) conclude there is a positive influence between board size and company performance. The results of research on Islamic compliant companies are conducted by (Abdullah, Hamid and Kamis, 1999) on Bursa Malaysia, showing the result that the board size does not effect on the firm performance. While (Bukair and Abdul Rahman, 2015)prove that the negative relationship between board size on the performance of Islamic banks. Reference (Haider, Khan and Iqbal, 2015) studied Islamic banks in Punjab Pakistan, showing the result that board size had a significant effect on the Bank's performance.

Furthermore, the board independence of Directors can contribute independently and actively participate in discussions at the board level, and represent shareholders on the company board. The company appointed board independence to monitor the performance of directors and top management, so they always concentrate on shareholder interests by maximizing shareholder value (Fuzi, Halim and Julizaerma, 2016). Several studies have found a positive influence between board independence and company performance such as ([(Dahya, Dimitrov and McConnell, 2008; Juras and Hinson, 2008; Black and Kim, 2012). While (Anum Mohd Ghazali, 2010) and (Hermalin and Weisbach, 2001)found that there is no significant relationship between board independence composition and firm performance. Reference (Bukair and Abdul Rahman, 2015) concluded that Board independence negatively affects the company's performance. These results contradict stakeholder theory.

\subsection{Enterprise Risk Management (ERM) and Firm Performance}

Implementation of risk management or better known as ERM is part of the implementation of corporate governance as a function of control in achieving corporate strategic goals. The ERM definition often referred to today is the framework of the Committee of Sponsoring Organizations of the Treadway Commission (COSO), which defines ERM as: "A process, influenced by boards of directors, management and other personnel, applied in strategy setting and across company, designed to identify potential events that may affect the entity, and manage risks in its risk appetite, to provide reasonable assurance about achieving the goals of the entity" (Enterprise Risk Management-Integrated Framework Executive Summary, 2004). Furthermore, Reference 
(Schroeck, 2002) explains that the application of risk management can lower agency costs and increase shareholder value.

Some researchers have shown evidence that the implementation of ERM is related to company performance. Research (Gordon, Loeb and Tseng, 2009; Hoyt and Liebenberg, 2011) in US companies shows that there is a positive influence between ERM and company performance. The same results were also concluded by (Ai Ping and Muthuveloo, 2015) at a listed Public Company (PLC) at Bursa Malaysia, and (Florio and Leoni, 2017) in Italy. But the results of different research shown by (Pagach and Warr, 2010) which concluded that ERM has no significant effect on company performance.

\section{Research Methodology}

The sample was selected using purposive sampling, firstly we selected 209 non-financial companies for 2011-2015 (1045 firms-years observations). Secondly, we excluded outlier to find the final sample of 953 observations, consisting of 95 Islamic compliant and 858 non-Islamic compliant firms.

\subsection{Variables and Measurement}

This research variables measurement presented in Table 1 below

Table 1. Variables Measurement

\begin{tabular}{|c|c|}
\hline Variable & Measurement \\
\hline $\begin{array}{l}\text { Firm } \\
\text { Performance } \\
\text { (Tobin's Q) }\end{array}$ & $\begin{array}{l}\text { The comparing the market value of equity } \\
\text { plus total debt divided by the book value of } \\
\text { equity plus total debt ([27] and [29]). }\end{array}$ \\
\hline $\begin{array}{l}\text { Board } \\
\text { (BS) }\end{array}$ & $\begin{array}{l}\text { The total of the company's board of } \\
\text { commissioners (Hermalin and Weisbach, } \\
\text { 2001; Florio and Leoni, 2017). }\end{array}$ \\
\hline ndence & $\begin{array}{l}\text { The number of the board independence } \\
\text { divided by the total board of commissioners } \\
\text { (Hermalin and Weisbach, 2001; Florio and } \\
\text { Leoni, 2017). }\end{array}$ \\
\hline e Risk & $\begin{array}{l}\text { The average score of ERM disclosure by } \\
\text { each firm. The scores were obtained based on } \\
\text { content analysis of the COSO-ERM } \\
\text { Framework consisting of } 78 \text { items of ERM } \\
\text { disclosure, each item uses a dichotomous } \\
\text { approach if disclosed given value } 1 \text {, and } 0 \text { for } \\
\text { the reverse (Sanusi et al., 2006; Desender, } \\
2007 \text { ). }\end{array}$ \\
\hline $\begin{array}{l}\text { Islar } \\
\text { Com }\end{array}$ & $\begin{array}{l}\text { Dummy variable where } 1 \text { company is } \\
\text { included in JII index (Islamic compliant } \\
\text { company) and } 0 \text { for others. }\end{array}$ \\
\hline $\begin{array}{l}\text { Profitability } \\
\text { (ROA) }\end{array}$ & $\begin{array}{l}\text { The relation between profit after tax and total } \\
\text { assets ((Hermalin and Weisbach, 2001; } \\
\text { Florio and Leoni, 2017) }\end{array}$ \\
\hline (Lev) & $\begin{array}{l}\text { The percentage of total debt to total assets } \\
\text { (Hermalin and Weisbach, 2001; Desender, } \\
\text { 2007; Florio and Leoni, 2017)). }\end{array}$ \\
\hline $\begin{array}{l}\text { The size of the } \\
\text { company } \\
\text { (SIZE) }\end{array}$ & $\begin{array}{l}\text { Natural Logarithm of total assets (Hermalin } \\
\text { and Weisbach, 2001; Desender, 2007; Florio } \\
\text { and Leoni, 2017)). }\end{array}$ \\
\hline
\end{tabular}

\subsection{Data Analysis}

Analysis data of this research using univariate and multivariate analysis. Univariate analysis is used to determine the differences in performance, ERM, Board independence, profitability, and corporate debt level between IC and Non-IC. While multivariate analysis is used to test the influence of each independent variables (BS, IB, ERM, and IC,) on firm performance (Tobin, s Q). Furthermore, to test whether Islamic Compliance (IC) have an effect on company performance can be known from the result of IC interaction with other independent variables. The research model is as follows: 
Tobin'sQ $=\beta_{0}+\beta_{1} \mathrm{BS}+\beta_{2} \mathrm{BI}+\beta_{3} \mathrm{ERM}+\beta_{4} \mathrm{ROA}+\beta_{5} \mathrm{Lev}+\beta_{6} \mathrm{Size}+\beta_{7} \mathrm{IC}+\beta_{8} \mathrm{IC} * \mathrm{BS}+\beta_{9} \mathrm{IC} * \mathrm{IB}+$ $\beta_{10} \mathrm{IC} * \mathrm{ERM}+\beta_{11} \mathrm{IC} * \mathrm{ROA}+\beta_{12} \mathrm{IC} * \mathrm{Lev}+\varepsilon \ldots$

\section{Result And Discussion}

\subsection{Descriptive Statistics}

Table 2 shows that the average firm performance (Tobin's Q) is 1.51. The average implementation of ERM of $0.49 \%$, indicates that implementation of ERM in the sample company tends to be at moderate levels. Profitability (ROA) shows an average of 0.05 that indicates the company's ability to generate profits is still low. Furthermore, the average board size (BS) is 4 person, while the proportion of board independence (IB) is $41 \%$. It indicates that the proportion of IB has complied with Indonesia SEC regulation.

Table 2. Descriptive Statistics

\begin{tabular}{|c|c|c|c|c|c|}
\hline Variable & $\mathbf{N}$ & Min & Max & $\begin{array}{c}\text { Mea } \\
\text { n }\end{array}$ & $\begin{array}{l}\text { Std. } \\
\text { Dev }\end{array}$ \\
\hline Tobin's & 95 & 0.13 & 12.3 & 1.51 & 1.13 \\
\hline $\mathrm{Q}$ & 3 & & 1 & & \\
\hline \multirow[t]{2}{*}{$\mathrm{BS}$} & 95 & 2.00 & 11.0 & 4.17 & 1.75 \\
\hline & 3 & & 0 & & \\
\hline \multirow[t]{2}{*}{$\mathrm{BI}$} & 95 & 0.20 & 0.80 & 0.41 & 0.10 \\
\hline & 3 & & & & \\
\hline \multirow[t]{2}{*}{$\overline{\text { ERM }}$} & 95 & 0.27 & 0.76 & 0.49 & 0.10 \\
\hline & 3 & & & & \\
\hline \multirow[t]{2}{*}{$\mathrm{ROA}$} & 95 & - & 9.56 & 0.05 & 0.34 \\
\hline & 3 & 1.73 & & & \\
\hline \multirow[t]{2}{*}{ Size } & 95 & 22.3 & 33.1 & 28.0 & 1.81 \\
\hline & 3 & 5 & 3 & 6 & \\
\hline \multirow[t]{2}{*}{ Lev } & 95 & - & 11.8 & 0.57 & 0.77 \\
\hline & 3 & 0.01 & 4 & & \\
\hline
\end{tabular}

\subsection{Correlation Analysis}

Table 3 below presents the statistical correlations among variables used in the regression analysis. The overall result shows the correlation coefficient of less than 0.8 . These results indicate that there is no multicollinearity problem in the regression analysis (Hair et al., 2014).

Table 3. Correlations Matix

\begin{tabular}{|c|c|c|c|c|c|c|c|}
\hline Var & $\begin{array}{l}\text { Tobin's } \\
\text { Q }\end{array}$ & BS & BI & ERM & ROA & Size & $\begin{array}{l}\mathrm{Le} \\
\mathrm{V}\end{array}$ \\
\hline BS & .05 & & & & & & \\
\hline BI & .02 & -.03 & & & & & \\
\hline $\begin{array}{l}\text { ER } \\
M\end{array}$ & $.08^{* *}$ & $.39^{* * *}$ & -.02 & & & & \\
\hline ROA & -.03 & $.16^{* * *}$ & -.05 & .02 & & & \\
\hline Size & $-.06^{*}$ & $.56^{* * *}$ & .04 & $.49^{* * *}$ & $.09^{* * *}$ & & \\
\hline Lev & $.64^{* * *}$ & $.10^{* * *}$ & $.14^{* * *}$ & $-.06^{*}$ & $.19^{* * *}$ & $.21^{* * *}$ & \\
\hline$\overline{\mathrm{IC}}$ & $.17^{* * *}$ & $.44^{* * *}$ & .01 & $.36^{* * *}$ & $.06^{*}$ & $.51^{* * *}$ & $\begin{array}{l}.05 * \\
\end{array}$ \\
\hline Notes & $*_{p}<0.1$ & $0 ; * * p$ & $<0.05 ;$ & $* * * p$ & $<0.01$ & & \\
\hline
\end{tabular}

4.2. Differences Performance, Governance Structure and ERM of Islamic Compliant and Non-Islamic Compliant

The univariate results of the analysis are shown in Table 4 below 
Table 4. Independent Samples t-Test

\begin{tabular}{|c|c|c|c|c|c|}
\hline $\begin{array}{c}\text { Variabl } \\
\text { e }\end{array}$ & $\begin{array}{c}\text { Categor } \\
y\end{array}$ & $\mathbf{N}$ & $\begin{array}{c}\text { Mea } \\
\mathbf{n}\end{array}$ & $\begin{array}{l}\text { Std. } \\
\text { Dev }\end{array}$ & t-stat \\
\hline \multirow[t]{2}{*}{$\begin{array}{l}\text { Tobin' } \\
\text { s Q }\end{array}$} & $\mathrm{IC}$ & 95 & 2.10 & 0.88 & $\begin{array}{l}5.45 * * \\
*\end{array}$ \\
\hline & Non-IC & 858 & 1.44 & 1.14 & \\
\hline \multirow[t]{2}{*}{$\mathrm{BS}$} & $\mathrm{IC}$ & 95 & 6.48 & 1.71 & $\begin{array}{l}15.09 * \\
* *\end{array}$ \\
\hline & Non-IC & 858 & 3.91 & 1.56 & \\
\hline \multirow[t]{2}{*}{ BI } & $\mathrm{IC}$ & 95 & 0.41 & 0.11 & 0.27 \\
\hline & Non-IC & 858 & 0.40 & 0.10 & \\
\hline \multirow[t]{2}{*}{ ERM } & $\mathrm{IC}$ & 95 & 0.60 & 0.08 & $\begin{array}{l}11.87 * \\
* *\end{array}$ \\
\hline & Non-IC & 858 & 0.48 & 0.10 & \\
\hline \multirow[t]{2}{*}{ ROA } & $\mathrm{IC}$ & 95 & 0.11 & 0.09 & $1.94 *$ \\
\hline & Non-IC & 858 & 0.04 & 0.36 & \\
\hline \multirow[t]{2}{*}{ Size } & $\mathrm{IC}$ & 95 & $\begin{array}{l}30.8 \\
1 \\
\end{array}$ & 0.93 & $\begin{array}{l}18.02 * \\
* *\end{array}$ \\
\hline & Non-IC & 858 & $\begin{array}{l}27.7 \\
6 \\
\end{array}$ & 1.62 & \\
\hline \multirow[t]{2}{*}{ Lev } & $\mathrm{IC}$ & 95 & 0.42 & 0.17 & $-1.67 *$ \\
\hline & Non-IC & 858 & 0.56 & 0.81 & \\
\hline \multicolumn{6}{|c|}{ Notes: $* p<0.10 ; * * p<0.05 ; * * * p<0.01$} \\
\hline
\end{tabular}

Table 4 above is the result of independent test samples t-test, Islamic compliant and nonIslamic compliant differences. These results indicate Islamic compliant provide better performance (Tobin's Q), higher board size (BS), and higher implementation of ERM than non-islamic compliant companies.

\subsection{Relationship of Governance Structure, implementation of ERM, and firm Performance}

Table 5 is the results of analysis using multiple linear regression, show that the value of $\mathrm{F}$ statistic is 81.633 and $p<0.01$, with adj R-square of 0.504 or $50.4 \%$. Furthermore, the test results show that the variable board size (BS) has no effect on the firm performance (Tobin's Q) for Islamic compliant and non-Islamic compliant, IC and BS interaction also showed no significant relationship.

\begin{tabular}{|c|c|c|c|}
\hline \multirow[t]{2}{*}{ Variable } & \multicolumn{2}{|c|}{ Coefficient Std. } & \multirow{2}{*}{$\begin{array}{l}\text { t- } \\
\text { statistics }\end{array}$} \\
\hline & & Error & \\
\hline $\begin{array}{l}\text { (Constan } \\
\text { t) }\end{array}$ & 1.696 & 0,508 & $\begin{array}{l}3.338 * * \\
*\end{array}$ \\
\hline BS & 0.009 & 0,020 & 0.435 \\
\hline BI & -0.797 & 0,276 & $\begin{array}{l}- \\
2.886^{* *} \\
*\end{array}$ \\
\hline ERM & 0.717 & 0,316 & $2.271 * *$ \\
\hline ROA & 0.228 & 0,079 & $\begin{array}{l}2.890 * * \\
*\end{array}$ \\
\hline LEV & 1.003 & 0,036 & $\begin{array}{l}28.179 * \\
* *\end{array}$ \\
\hline Size & -0.032 & 0,020 & -1.591 \\
\hline $\mathrm{IC}$ & 2.569 & 0,800 & $\begin{array}{l}3.211^{* *} \\
*\end{array}$ \\
\hline IC*BS & -0.040 & 0,055 & -0.732 \\
\hline IC*BI & 0.020 & 0,810 & 0.025 \\
\hline $\begin{array}{l}\mathrm{IC}^{*} \mathrm{ER} \\
\mathrm{M} \\
\end{array}$ & -0.908 & 1,034 & -0.877 \\
\hline $\mathrm{IC} * \mathrm{ROA}$ & 3.754 & 0,933 & $\begin{array}{l}4.023^{* *} \\
*\end{array}$ \\
\hline IC*LEV & -3.287 & 0,521 & - \\
\hline
\end{tabular}




\begin{tabular}{ccc}
\hline $\begin{array}{c}\text { Variable Coefficient Std. } \\
\text { s }\end{array}$ & Error & $\begin{array}{l}\text { t- } \\
\text { statistics }\end{array}$ \\
\hline & $\begin{array}{l}6.304 * * \\
*\end{array}$ \\
\hline Adj R-square $0.504 ;$ & F-Stat & $81.633 * * *$ \\
\hline Notes: $* p<0.10 ; * * p<0.05 ; * * * p<0.01$ \\
\hline
\end{tabular}

The independence board (IB) is negatively related to the firm performance (Tobin's Q), but IC and IB interactions do not show significant relationship. Furthermore, ERM has a significant positive effect on performance (Tobin's Q). However, IC and ERM interaction results did not show significant relationship.

The test results for the ROA control variable indicate there is a positive influence between ROA and Tobin's Q, as well as IC and ROA interaction results, show a significant relationship with Tobin's Q. These results are consistent specifically for Islamic compliant companies. Different results are indicated by leverage (Lev) variables in the overall Islamic compliant and non-Islamic complaint, indicating a positive relationship with performance (Tobin's Q). In contrast, the results of IC and Lev interactions show a negative relation with firm's performance (Tobin's Q). Furthermore, firm size (Size) has no effect on a company's market performance. The Islamic compliant (IC) is positively influence to firm's performance (Tobin's Q).

\section{Conclusions}

This study found that firm performance, board size, implementation of ERM in Islamic compliant is higher than non-Islamic compliant. Meanwhile, the board independence has the same proportion of both Islamic compliant and non-Islamic compliant. The also found that board size has no relation to the firm's performance for both Islamic compliant and non-Islamic compliant. Moreover, this study provides an empirical evidence that board independence negatively influences firm performance both Islamic compliant and non-Islamic complain. However, for Islamic compliant subsample, this study found board independence is no relation to firm performance. Instead, implementation of ERM has a significant positive effect on firm performance. However, for Islamic compliant companies, this study did not find the relationship between the implementation of ERM and firm performance.

\section{References}

[1] Abdullah, A., Hamid, M. A. and Kamis, N. A. M. (1999) 'Board Characteristics, Company of Origin and Performance: A Study of Malaysian Shari' ah -Compliant Listed Companies', pp. 86-97.

[2] Ai Ping, T. and Muthuveloo, R. (2015) 'The impact of enterprise risk management on firm performance: Evidence from Malaysia', Asian Social Science, 11(22), pp. 149-159. doi: 10.5539/ass.v11n22p149.

[3] Anum Mohd Ghazali, N. (2010) 'Ownership structure, corporate governance and corporate performance in Malaysia', International Journal of Commerce and Management. Emerald Group Publishing Limited, 20(2), pp. 109-119. doi: 10.1108/10569211011057245.

[4] Arham, M. (2010) 'Islamic perspectives on marketing', Journal of Islamic Marketing. Emerald Group Publishing Limited, 1(2), pp. 149-164. doi: 10.1108/17590831011055888.

[5] Beekun, R. (1997) Islamic Business Ethics. Herndon: The International Institute of Islamic Thought.

[6] Black, B. and Kim, W. (2012) 'The effect of board structure on firm value: A multiple identification strategies approach using Korean data', Journal of Financial Economics. North-Holland, 104(1), pp. 203-226. doi: 10.1016/J.JFINECO.2011.08.001.

[7] Bukair, A. A. and Abdul Rahman, A. (2015) 'Bank performance and board of directors attributes by Islamic banks', International Journal of Islamic and Middle Eastern Finance and Management. Emerald Group Publishing Limited , 8(3), pp. 291-309. doi: 10.1108/IMEFM-10-2013-0111.

[8] Chapra, M. U. and Ahmed, H. (2009) 'Chapter 7 . Corporate Governance for', in A Primer on Islamic Finance Corporate. Islamic Re. Islamic Development Bank, pp. 81-91.

[9] Chin, T., Vos, E. and Casey, Q. (2004) 'LEVELS OF OWNERSHIP STRUCTURE, BOARD COMPOSI-TION AND BOARD SIZE SEEM UNIMPORTANT IN NEW ZEALAND', Corporate Ownership \& Control, 2(1). Available at: http://www.virtusinterpress.org/IMG/pdf/cocv2ilp9.pdf (Accessed: 15 January 2019). 
[10] Dahya, J., Dimitrov, O. and McConnell, J. J. (2008) 'Dominant shareholders, corporate boards, and corporate value: A cross-country analysis', Journal of Financial Economics. North-Holland, 87(1), pp. 73-100. doi: 10.1016/J.JFINECO.2006.10.005.

[11] Desender, K. (2007) 'On the Determinants of Enterprise Risk Management Implementation', Enterprise IT Governance, Business Value and Performance Measurement, pp. 87-100. doi: 10.4018/978-1-60566-346-3.ch006.

[12] Enterprise Risk Management-Integrated Framework Executive Summary (2004). Available at: www.aicpa.org, (Accessed: 15 January 2019).

[13] Farooq, O. and Alahkam, A. (2016) 'Performance of shariah-compliant firms and nonshariah-compliant firms in the MENA region', Journal of Islamic Accounting and Business Research. Emerald Group Publishing Limited , 7(4), pp. 268-281. doi: 10.1108/JIABR-102013-0039.

[14] Florio, C. and Leoni, G. (2017) 'Enterprise risk management and firm performance: The Italian case', The British Accounting Review. Academic Press, 49(1), pp. 56-74. doi: 10.1016/J.BAR.2016.08.003

[15] Fuzi, S. F. S., Halim, S. A. A. and Julizaerma, M. K. (2016) 'Board Independence and Firm Performance', Procedia Economics and Finance. Elsevier, 37, pp. 460-465. doi: 10.1016/S2212-5671(16)30152-6.

[16] Ghosh, I. (2014) 'VALS TM Psychographic: A New Way of Market Segmentation in India Abstract ':, the International Journal of Business \& Management, 2(4), pp. 25-30.

[17] Gordon, L. A., Loeb, M. P. and Tseng, C.-Y. (2009) 'Enterprise risk management and firm performance: A contingency perspective', Journal of Accounting and Public Policy. Elsevier, 28(4), pp. 301-327. doi: 10.1016/J.JACCPUBPOL.2009.06.006.

[18] Haider, N., Khan, N. and Iqbal, N. (2015) 'Impact of corporate Governance on Firm Financial Performance in Islamic Financial Institution', International Letters of Social and Humanistic Sciences, 51, pp. 106-110. doi: 10.18052/www.scipress.com/ILSHS.51.106.

[19] Hair, J. F., Black, W. C., Babin, B. J. and Anderson, R. E. (2014) Multivariate data analysis, Pearson custom library. doi: 10.1038/259433b0.

[20] Hermalin, B. and Weisbach, M. (2001) Boards of Directors as an Endogenously Determined Institution: A Survey of the Economic Literature. Cambridge, MA. doi: 10.3386/w8161.

[21] Hoyt, R. E. and Liebenberg, A. P. (2011) 'The Value of Enterprise Risk Management', Journal of Risk and Insurance. John Wiley \& Sons, Ltd (10.1111), 78(4), pp. 795-822. doi: 10.1111/j.1539-6975.2011.01413.x.

[22] JENSEN, M. C. (1993) 'The Modern Industrial Revolution, Exit, and the Failure of Internal Control Systems', The Journal of Finance. John Wiley \& Sons, Ltd (10.1111), 48(3), pp. 831-880. doi: 10.1111/j.1540-6261.1993.tb04022.x.

[23] Juras, P. E. and Hinson, Y. L. (2008) 'Examining the Effect of Board Characteristics on Agency Costs and Selected Performance Measures in Banks (Report) by Academy of Banking Studies Journal on Apple Books', Academy of Banking Studies Journal, 7.

[24] Kumar Adhikary, B., Huynh Gia Hoang Bishnu Kumar Adhikary, L. and Huynh Gia Hoang, L. (2014) 'Board Structure and Firm Performance in Emerging Economies: Evidence from Vietnam', Ruhuna Journal of Management and Finance, 1(1). Available at: http://www.mgt.ruh.ac.lk/rjmf/pdfs/RJMF0101 JA p53.pdf (Accessed: 15 January 2019).

[25] Nisha, N. and Ghosh, B. (2018) 'Causal relationship between leverage and performance: exploring Dhaka Stock Exchange', International Journal of Business and Globalisation, 20(1), p. 31. doi: 10.1504/IJBG.2018.10009520.

[26] Omran, M. F. (2009) 'Examining the Effects of Islamic Beliefs on the Valuation of Financial Institutions in the United Arab Emirates', Review of Middle East Economics and Finance. De Gruyter, 5(1), pp. 72-79. doi: 10.2202/1475-3693.1127.

[27] Pagach, D. P. and Warr, R. S. (2010) 'The Effects of Enterprise Risk Management on Firm Performance', SSRN Electronic Journal. doi: 10.2139/ssrn.1155218.

[28] Pearce, J. A. and Zahra, S. A. (1992) 'BOARD COMPOSITION FROM A STRATEGIC CONTINGENCY PERSPECTIVE', Journal of Management Studies. John Wiley \& Sons, Ltd (10.1111), 29(4), pp. 411-438. doi: 10.1111/j.1467-6486.1992.tb00672.x.

[29] Safieddine, A. (2009) 'Islamic Financial Institutions and Corporate Governance: New Insights for Agency Theory', Corporate Governance: An International Review. John Wiley \& Sons, Ltd (10.1111), 17(2), pp. 142-158. doi: 10.1111/j.1467-8683.2009.00729.x.

[30] Sanusi, Z. M., Ismail, R., Hudayati, A. and Harjito, D. A. (2006) 'Screening process of Shariah-compliant companies: The relevance of financial risk management', International Journal of Economics and Management. Faculty of Economics and Management, 9(1), pp. 177-195. 
[31] Schroeck, G. (2002) Risk Management and Value Creation in Financial Institutions. doi: 10.1007/3-540-26993-2 3.

[32] Yermack, D. (1996) 'Higher market valuation of companies with a small board of directors', Journal of Financial Economics. North-Holland, 40(2), pp. 185-211. doi: 10.1016/0304-405X(95)00844-5. 